\title{
Vocational Proficiency Education In Boarding Schools
}

\author{
Retno Anisa Larasati, Iim Wasliman, Hanafiah, Waska Warta \\ Nusantara Islamic University, Bandung, Indonesia \\ Nusantara Islamic University, Bandung, Indonesia \\ Nusantara Islamic University, Bandung, Indonesia \\ Email: retno924@gmail.com, iim_wasliman@yahoo.com, hanafia@uninus.ac.id, \\ waskawarta@gmail.com
}

\begin{tabular}{|c|c|}
\hline ARTICLE INFO & ABSTRACT \\
\hline $\begin{array}{l}\text { Received } \\
23 \text { Juny } 2021 \\
\text { Revision } \\
1 \text { July } 2021 \\
\text { Approved } \\
10 \text { July } 2021 \\
\text { Keywords: } \\
\text { vocational skills education } \\
\text { entrepreneurial spirit of sar }\end{array}$ & $\begin{array}{l}\text { The purpose of this research is to describe and describe, } \\
\text { vocational proficiency education in Boarding Schools. Grand } \\
\text { Teory in this study uses the theory from Terry (1958) dividing } \\
\text { the four basic functions of management, namely Planning, } \\
\text { Organizing, Actuating and Controlling. The results showed that } \\
\text { vocational skills education in an effort to improve the } \\
\text { entrepreneurial spirit in boarding schools is still not maximal. } \\
\text { It is proven that only a few Boarding Schools graduates have } \\
\text { an entrepreneurial spirit. Vocational proficiency education in } \\
\text { boarding is more likely to provide theory than practice so that } \\
\text { the learning stategi provided is less comprehensive, } \\
\text { innovative, and creative. }\end{array}$ \\
\hline
\end{tabular}

\section{INTRODUCTION}

Boarding School is an educational institution that is deeply rooted in society. In general, boarding live, from, by and for the community. boarding try to educate the students, then can teach it to the community. The existence of Boarding Schools becomes special because it becomes an alternative education (balancing) education developed by the colonials so that it is expected to grow intellectuals who are insightful with a strong spiritual foundation.

Admittedly or not, Boarding Schools with various forms and variations of the learning process is part of the nation's civilization that has been firmly attached in the nation's history. The advantage of Boarding Schools lies in the principle of "humanizing people" in the learning process (Abdullah, 2007). Boarding will still exist as an Islamic educational institution that has a vision of printing human beings.

As explained by Farida Hanun (2018 : 14): Boarding that initially only educate students to have skills to religion, now must be able to answer more challenges and more realistic. The social problems faced by the community are increasingly complex. Population density and intense competition so that strong skills and personalities are needed to be successful in life.

Life skill education for students is useful as a provision in dealing with and solving life problems. In addition, life skill education can also reduce dependence on employment or reduce unemployment and increase productivity for the community. So it is very appropriate if life skill education is included in the curriculum of boarding schools.

As explained by (Azra, 1999) that the boarding response to the issue of boarding system renewal in the midst of the current changes to economic issues is to include the substance of education by including general lessons and life skills, renewal of learning methods by changing the bandongan system to classical, as well as institutional reforms that include the repositioning of the role of

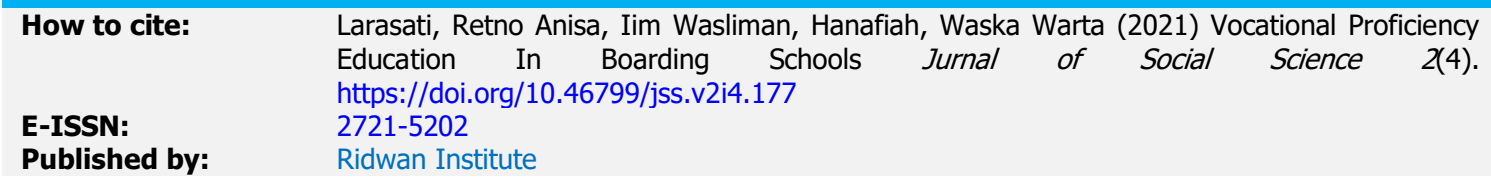


kyai, orientation (mission vision) pondok pesanten, as well as its managerial aspects.

Life skill development program has been regulated by Law No. 20 of 2003, Article 3 on functions and objectives stated: National education serves to develop capabilities and form the character and civilization of a dignified nation in order to educate the life of the nation, aiming to develop the potential of learners to become human beings who believe and fear God Almighty, noble character, healthy, knowledgeable, capable, creative, independent, and become a democratic and responsible citizen.

The importance of life skill development is contained in Law No. 20/2003 on National Education System (Sisdiknas) Article 26 paragraph 1:

Non-Formal Education is organized for citizens who need educational services that serve as substitutes, enhancers, and/or complements formal education in order to support lifelong education. Furthermore, paragraph 3 reads:

Life skills education is an education that provides personal skills, social skills, intellectual skills, and vocational skills for work or independent business.

The Government Regulation No. 55 of 2007 concerning Religious Education and Religious Education Article 2 reads:

Religious education aims to develop the ability of learners in understanding, living, and practicing religious values that harmonize mastery in science, technology, and art.

Then in Law No. 18 of 2019 is also explained in article 3 point $b$ which reads: Boarding held with the aim of:

a. forming superior individuals in various fields who understand and practice the value of their religious teachings and or become experts in religious sciences who believe, fear, noble character, knowledgeable, independent, helpful, balanced, and moderate;

b. establish a moderate understanding of religion and religion and love of the homeland and form behaviors that encourage the creation of religious harmony; and c. improving the quality of life of a society that is empowered in meeting the educational needs of citizens and the social welfare of the community.

Based on the above legislation, boarding have a golden opportunity in the implementation of vocational skills so that students in addition to being given a deepening of religious knowledge, also need to be given strengthening skills as a provision of life in the community. This is in accordance with the educational ideals of boarding schools that produce independent students so as not to depend on others. When compared to formal educational institutions, boarding schools are seen as able to form independent living students.

According to islamic education statistics data in 2018/2019 from the Directorate General of Islamic Education ministry of Religion of the Republic of Indonesia (2019: 45 ), out of a total of 27,290 boarding spread throughout Indonesia as many as 13,336 ( $48.87 \%$ ) traditional boarding schools and $13,954(51,13 \%)$ is a modern boarding.

The boarding that develop socioeconomic functions according to Farida Hanun (2018: 16) in the form of life skills activities in the field of handicrafts there are a number of $4825(28 \%)$ boarding which include: webbing as much as 703 (4\%) boarding, food as much as 985 (5.6\%) boarding, carpentry as much as $1532(8.8 \%)$ boarding, brick 859 (4.9\%) boarding, and convection as much as 746 (4.3\%) Boarding.

Looking at the fact above it turns out that in the boarding school education system both traditional and modern boarding schools students in addition to being equipped with religious sciences are also equipped with a variety of life skills education whose purpose is to create students to create jobs (especially for students who can not continue higher after graduation, then when returning to the community requires readiness skills).

Life skill education problem is an unsolved problem in line with the complexity of environmental change, both in terms of planning, implementation and assessment especially related to the improvement of entrepreneurship.

Based on data from the Indonesian Young Entrepreneurs Association (2017) mentioned, until now indonesian youth who engaged or became an entrepreneur turned out to be only three percent of the total population of about 260 million people. This percentage does not grow, when compared to neighboring countries. Neighboring countries have reached five to seven percent. The level of 'entrepreneur' in Indonesia does 
not rise because there is no government space for entrepreneurial youth.

Boarding that organize life skill activities, by the government is usually called vocational boarding. Vocational boarding school is one of the program activities of the Ministry of Religious Affairs directed at the participation of boarding schools in following the education of skills or life skills. However, the reality in the field shows that there are still many boarding that have not been able to develop the maximum vocational skills activities.

Some preliminary research on boarding schools in Indonesia causes some differences in life skills education in some boarding.

The first research conducted by (Cahyono, 2017) entitled "Entrepreneurial Education Management" shows the problem that the education model is not running well because it has not met certain conditions, such as the absence of a clear job description in each field, including its rights and authority in the implementation of entrepreneurial education.

The second research conducted by Sopwan (2017: 76) with the title "Life Skill in boarding" shows that the problem of life skills education in Pondok Narul Hayah Yogyakarta applies all life skills activities ranging from generic life skills and specific life skills so that students are less optimal to develop life skills that suit their interests and talents.

The third research conducted by (Khamidah, 2018) with the title "Entrepreneurship Education in boarding" shows that, the problem of entrepreneurial education in Yayasan Pondok boarding Modern Yatim and Dhuafa Madania Yogyakarta is too much to develop various fields so that the process of entrepreneurship education and life skills do not run smoothly and progress because there are less supporting factors than in the Boarding itself.

The fourth research conducted by Farida Hanun (2018: 78) with the title "Improving Student Independence Through The Implementation of Life Skills in boarding " shows that the implementation of vocational skills in boarding Sumatra Thawalib Parabek West Sumatra is carried out with several sectors so that this Boarding Schools needs innovative resources. However, the reality in the field of boarding does not yet have innovative resources.
The reason for the selection of boarding Al Jawahir Soreang and boarding Al Fadlilah Limbangan because these two Boarding Schools are Islamic educational institutions that get the help of OPOP (One Boarding Schools One Product) program from West Java Province, have graduates who are mostly entrepreneurial and are Boarding Schools have been established for quite a long time.

\section{METHOD}

This study uses qualitative approach with case study design. The reason for using this method is based on the consideration that the data to be searched is the root of the depiction of the purpose of the program, implementation, and evaluation of vocational proficiency education programs in boarding schools that require researchers to observe the entrepreneurial attitudes that students have and interact directly with them about vocational proficiency education and entrepreneurial spirit so that for that researchers must go down directly to the field like a detekti f, spy, explorer or journalist.

\section{RESULTS AND DISCUSSION}

\section{Findings from Boarding Schools Al Jawahir Soreang Bandung Regency}

Description of the findings in the research conducted at Boarding Schools Al Jawahir related to vocational skills education in the improvement of entrepreneurial spirit of students including vocational skills education developed, entrepreneurial values developed, implementation of vocational skills education, evaluation of vocational skills education, partnerships, demands and expectations, problems, anticipatory efforts and measures, and development models.

\section{a. Vocational Proficiency Education \\ 1) Types of Vocational Proficiency Education \\ From the results of interviews,} observations, and documentation, it can be explained that vocational proficiency education in Boarding Schools Al Jawahir Soreang is a planned and organized effort in providing productive skills and skills according to interests and talents as a 
provision in an effort to meet the needs of life.

Vocational skills education developed in Boarding Schools Al Jawahir Soreang focuses on sewing and processing skills tempeh.

In sewing skills, students are expected to have the ability to understand the basics of sewing theory, make their own clothes and practice them for others. In addition, students are also invited to develop their skills to the advanced or advanced level and work independently according to their skills as a provision of their lives. While in the tempeh making program, it is expected that students can improve skills in the field of tempe production which will later become a support for the creative economy in the community.

2) Why Boarding Schools Choose This Type of Vocational Proficiency Education

From the results of interviews, observations, and documentation can be explained that the reason Boarding Schools Al Jawahir Soreang choose life skills vocational education in sewing skills, namely:

\section{a) Affordable Initial Capital}

Sewing business is a business whose capital was initially affordable. First, the business capital prepared Boarding Schools Al Jawahir Rp 5.500.000 only, This money can be used to buy one sewing machine, chairs, threads, needles, meters, and other sewing tools.

\section{b) Basic skills}

This business can still run even with the most basic skills, such as cutting, measuring, and creating patterns. This means that students do not have to take sewing courses and pay for course fees. Moreover, orders to be sewn are still common, such as tablecloths, curtains, bed linen, and doormats.

Sewing skills will develop by themselves if the students have been sewing for many years. Because the incoming orders will automatically increase, both in quantity, type, and model. So indirectly students are forced to deepen the science of sewing.

\section{c) The benefits are decent}

This business does not need to rent a special place for sewing, paying security, hygiene, and electricity money. So all the absolute profits for the advancement of Boarding Schools, capital to buy materials, as well as saved to grow the business.

For example, the net profit obtained by Boarding Schools is Rp $150,000 /$ stitch. While in one month, students can get orders as many as 20 pieces. If totaled, then the profit

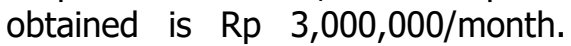
This count is still for small-scale stitching businesses. If the scale of the seam business is large, then the profit can be up to $5 x$ per month.

d) The rest of the material can be stitched back

If the material or clothing will be from the previous stitch remains, students can use it to make new clothes. The rest of the material can be put together until it forms a wide cloth, then sewn as usual.

e) Promotion of business is simple Sewing business is not like laundry business, photocopying, or food stalls that must print brochures or banners for promotional activities. Because, word of mouth promotion alone is powerful enough to bring in new customers. So, Boarding Schools do not need to prepare special costs for the promotion of sewing business.

The money that has been set aside is used for other purposes. For example, buying sewing equipment, repairing the machine if there is damage, or hiring students if they want to enlarge the seam effort.

\section{f) Fast Growing}

The time it takes to develop a sewing business is not long. In just 6 months, this business can grow rapidly as long as the seam quality is good. Good here is not only durable, but also has a model that is not 
outdated and comfortable when worn. If the stitching of students has this quality, then the development of the business is faster than imagined.

The reason Boarding Schools Al Jawahir Soreang chose vocational skills education in the business of making tempeh, namely:

\section{a. Raw Materials}

Tempe raw materials are quite easy to get. Students can go to the Traditional Market to get it. At the beginning of this business, still experiments santri buy soybeans $5 \mathrm{~kg}$ and tempeh yeast 20 grams, and water to taste.

\section{b. Equipment}

Equipment in the process of making tempeh is also easy to get such as large slaps, baskets, buckets, wood mixers, molds, boilers, burlap sacks, furnaces or stoves.

\section{c. Tempe Rich in Benefits}

Tempe is a typical Indoesian food that is favored by the public at large. Tempe is one of the processed products based on biotechhnology.

d. Tempe Production Can Be Done Easily

Tempeh production can be done easily by using soybeans and yeast as the main ingredients. How to make it is also easy. The selected soybeans are then washed thoroughly, boiled for about 60 to 90 minutes, soaked until the skin peels, seasoned with yeast, then wrapped in plastic, banana leaves, or teak leaves. After going through the process of acidification for 36/48 hours tempeh can be consumed. Tempe production can be done in small amounts at home to meet their own needs or massively for commercial purposes. Tempe production is very suitable in practice in all regions.

\section{3) Vocational Proficiency Education} Success Indicators

From the results of interviews, observations, and documentation can be explained that indicators of the success of vocational proficiency education in Boarding Schools Al Jawahir see from the activities in the implementation process and after the implementation of vocational proficiency education in Boarding Schools. Indicators of the success of sewing skills are seen when students already have six basic competencies, namely:

a) Have ideas in starting basic sewing skills

b) Selecting a needle size

c) Create a simple straight stitch pattern

d) Add stitch patterns with more complex elements and techniques

e) Practicing sewing skills by hand and sewing machine

f) Recycle clothes by sewing and transforming them into other shapes.

Indicators of the success of tempeh making are seen when students already have five basic competencies, namely:

a) Have ideas in starting tempeh making

b) Choosing raw materials

c) Practice the process of making tempeh

d) Practicing the fermentation process

e) Pay attention to the cleanliness of work and cleanliness of work equipment

4) Vocational Skills Education Planning Document

From the results of interviews, observations, and documentation can be explained that Boarding Schools Al Jawahir Soreang has several planning documents for vocational skills education planning program contained in the Boarding Schools program document consisting of:

a) Long-term Boarding Schools program or Long-Term Boarding Schools Work Plan (RKPJP). RKPJP is between 8-10 years old.

b) Medium-term Boarding Schools program or Medium Term Boarding School Work Plan (RKPJM). RKPJM is between 4-5 years old.

c) Short-term Boarding Schools program or Annual Boarding 
Schools Work Plan (RKT). CTR is between 1 year. RKT translates the vision, mission, and objectives of the current school year which must be identified the real challenges.

Boarding Schools program that is prepared should pay attention to several things, namely environmental analysis, SWOT, vision, mission, and school objectives. RKPJP, RKPJM, RKT is a series of work plans that are mutually sustainable and are constantly analyzed for achievement.

5) Sources of Funding in Vocational Proficiency Education

From the results of interviews, observations, and documentation can be explained that the source of funds in vocational proficiency education in Boarding Schools Al Jawahir consists of donors, parents donations, government assistance, and business units Boarding Schools. Boarding Schools Al Jawahir has donors, namely a Notary in soreang area who regularly provides funds for vocational proficiency education, parents who have a middle income and above are also required to make donations for underprivileged students, Boarding Schools Al Jawahir has worked with the Cooperative and MSMEs Office of West Java Province in 2019 in the OPOP (One Boarding Schools One Product) program.

One Boarding Schools One Product (OPOP) program aims to create the independence of the people through the students, the community and the Boarding School itself, in order to be able to be economically, socially independent and also to spur the development of skills, production technology, distribution, marketing through an innovative and strategic approach from the Provincial Government of West Java along with the Kukm Office of West Java Province, ensuring that all Boarding Schools in West Java can gain access to government programs in the pemb sector. economic power, technology and production are efficient, precise and modern in today's digital agei.

\section{b. Entrepreneurial Values}

1) Nilai-Nilai

Pendidikan

Kecakapan vokasional yang dikembangkan

From the results of interviews, observations, and documentation can be explained that the entrepreneurial values developed in Boarding Schools Al Jawahir more towards the psychomotor aspect (able to realize yourself (selfactualization) optimally in accordance with the potential, interests, and abilities that have so that tough attitude, abstinence from complaining, faith, creative, optimism, courage, patience, generosity, honesty, independence, and laughter to Allah SWT will be owned by Santri that method developed to improve the entrepreneurial spirit given usually in the form of life skills, simulation, internships, business látihan, etc.

2) Boarding School Method in Developing Entrepreneurial Spirit of Santri

From the results of interviews, observations, and documentation can be explained methods for the improvement of entrepreneurial spirit students in Boarding Schools Al jawahir one of them business practices. For example, by selling the products that have been made in Sabilulungan Sunday Market and internships at the Boarding Schools Al Jawahir Cooperative for example by making cooperative financial statements. The learning methods used are lectures, discussions, assignments, Q\&A, experiments, demonstrations, and simulations. While the learning media used LCD / screen, whiteboard, markers, wireless and laptop.

\section{3) Internalization Process of Entrepreneurial Values of Students}

Internalization

of entrepreneurial values begins when students receive and live the learning materials, respond by asking or being enthusiastic, respecting the values conveyed, organizing the values they receive 
to be applied, so that habituation occurs that gives birth to religious mindsets, attitudes, and entrepreneurial behaviors.

c. Vocational Proficiency Education Implementation Process

1. Development of Vision, Mission, and Objectives

From the results of interviews, observations, and documentation can be explained that the process of implementation of vocational proficiency education in Boarding Schools Al Jawahir starts from the development of vision, mission, and objectives. The vision of Boarding Schools Al Jawahir "Sowing Islamic morality, Towards Civil society, Reaping the happiness of Ukhrowi'. From this vision was developed on the mission of:

a. Educating students to be a generation of intelligent and knowledgeable nation.

b. Educating students to have life skills both soft skills and hard skills.

c. Educate students in a balanced manner religious knowledge and general knowledge in order to form a complete human being (Insan Kamil).

d. Educate students to be a generation that has a strong aqidah and noble character.

e. Educating students to be a generation of intelligent and knowledgeable nation. Educating students to have life skills both soft skills and hard skills.

f. Educate students in a balanced manner religious knowledge and general knowledge in order to form a complete human being (Insan Kamil).

g. Educate students to be a generation that has a strong aqidah and noble character.

Based on the statement of the vision and mission of Boarding Schools is very clearly visible on the 2nd mission yatu educate students to have life skills both soft skills and hard skills so that the purpose of the implementation of vocational proficiency education is expected after graduation students can improve life skills in work or selfentrepreneurship.

\section{Analysis of Vocational Proficiency Education Needs}

From the results of interviews, observations, and documentation can be explained that the analysis of identification of santi needs begins at the preparation of the implementation of vocational proficiency education consists of steps of need identification, resource identification, program preparation, organizing of program implementers, and cooperation agreements with program partners.

Identification needs is the activity of inventorying the type of skills required by students in accordance with their potential and interests and the surrounding environment. How to identify needs, among others, through interviews to explore the desire of students, observation of superior products of the region, and market share surveys. Identification of needs results in determination of the types of skills that suit the conditions of students and the community.

3. Preparation of Vocational

\section{Proficiency Education Plan}

From the results of interviews, observations, and documentation can be explained that the preparation of vocational proficiency education program plans, identiflcation of needs and identification of resources are two important components. Resource identification is the activity of inventory and organizing all materials, tools, facilities, funds, and facilitators (teachers and or professionals) and partners. Partners are other parties that can assist vocational skills education activities, both in the training process, the provision of materials, sources of funds, educators, and in product marketing.

Program preparation is the design of pre-vocational activities 
that will be conducted including socialization, orientation, learning (theory and practice), evaluation and follow-up.

\section{Organizing}

Organizing

implementation includes the establishment of organizational structure, personnel determination, division of tasks, and mechanism of action. The task and function of Boarding Schools leaders is to determine the policy of program implementation. In terms of determining the policy the principal is expected to: (1) Establish vocational programs that have educational and economic value based on the results of identification of needs and deliberations; and (2) Determining policies related to the implementation of vocational programs (e.g. issuing Management Decrees, mechanisms of action, cooperation agreements, licensing, and so on).

The head of the program is a skill teacher who has competence in accordance with the developed program. The duties and functions of the program chairman consist of: (1) Coordinating all activities covered in the program; (2) Monitor the implementation of the program; and (3) Report on the progress and results of the implementation of the program. In the implementation of vocational proficiency education in Boarding Schools Al Jawahir is the responsibility of the Deputy Leader of Boarding Schools as the Program's Responsibility.

\section{Parties involved}

From the results of interviews, observations, and documentation can be explained that the parties involved in vocational proficiency education in Boarding Schools Al Jawahir began with a cooperation agreement with partners.

a. Cooperation Agreement with Partners.

b. Program Participant Networking.

\section{Vocational} Education Procedures
From the results of interviews, observations, and documentation can be explained that the vocational proficiency education procedures implemented in Boarding Schools Al Jawahir begin with socialization, orientation and learning.

\section{a. Socialization}

Socialization is an activity aimed at disseminating information and equating perceptions about vocational programs to all parties directly or indirectly related. Socialization can be reached in the form of meeting activities, poster dissemination, announcement spread, and so on.

\section{b. Orientation}

Orientation is an activity that aims to introduce vocational programs to students, in order to motivate them to actively participate in learning and develop entrepreneurial insights. Orientation activities are carried out both inside and outside the school in the form of the following activities: introducing the types of skills to be given; (2) determine the time and place of implementation of learning activities both theory and practice; (3) explain the process of vocational activities; (4) Explain the benefits of participating in vocational activities; and (5) introduce teachers.

\section{c. Learning}

Vocational program learning
steps include pre-learning,
learning process, and end of
learning.

1. Pre-learning.

At this stage it is necessary to take the following steps:

Identify the type of skills to be taught; Preparation of learning materials and tools; Setting the learning schedule; Preparation of learning places; Preparation of learning strategies and 
methods; and Development of evaluation tools.

\section{Learning process}

The learning process is an interaction between skill teachers and student participants in order to develop life skills through mastery of learning materials. Learning includes the following steps: (1) connecting the learning experience that students have with the learning materials to be delivered; (2) presentation of materials in the form of training and practice; and (3) evaluation of learning.

\section{End of learning}

At the end of each vocational learning, it is necessary to evaluate the learning outcomes. This evaluation is focused on measuring the achievement of technical competencies and indicators of life skills mastered by students. The success of learning is seen from the mastery of learners to both components. Methods / evaluations that can be used to measure the process and achievement of learning outcomes can be in the form of tests, non-tests, and portfolios. The test instrument can be a writing test. oral tests and action tests. Non tests in the form of observations, interviews, inventory mapun scale. Portfolio is a collection of results from tests and nontests that describe the ability / competence of students.

\section{d. Evaluation of Vocational Proficiency Education Implementation I}

From the results of interviews, observations, and documentation can be explained that the evaluation of vocational proficiency education programs conducted in Boarding Schools Al Jawahir is an activity to see the effectiveness of the implementation of vocational programs. Evaluation is conducted in the form of data collection, study, and information about the implementation of the program. The evaluation of vocational programs is intended to obtain information about the implementation of the program, which is used to make further improvements or development of the program.

In detail the evaluation is intended to obtain information about (1) the suitability of the implementation of vocational programs with the plan that has been drawn up; (2) factors inhibiting the implementation of the program; (3) the steps that have been taken by the program implementers in order to overcome the problems arising; and (4) the implementation of vocational programs.

The aspects evaluated in this vocational proficiency education program include preparation, socialization, orientation, learning, and evaluation.

(a) Preparation and planning of the program. In this aspect the evaluation is conducted to see the suitability of the selected vocational proficiency education program with local potential, the interests and characteristics of students, and the availability of educational resources.

(b) Socialization. Evaluation on this aspect is conducted to determine the effectiveness of the delivery of information about the program to related parties.

(c) orientation. Evaluation is conducted on the orientation aspect intended to see students' understanding of 
the purpose, purpose, and benefits. From the vocational program that will be implemented and know the efforts of the manager in motivating students to participate in the activity.

(d) Human resources. Resource evaluation is focused on optimizing various resources in supporting vocational programs and ways of involvement.

(e) implementation. Evaluation of aspects of the implementation of the program is carried out to see the suitability of the implementation of the program (learning / training) with the plan that has been made, the obstacles experienced during the implementation of the program, and the efforts made by Boarding Schools.

1. Alumni Search

In addition to the five aspects above, Boarding Schools Al Jawahir also every year always routinely conducts the search for alumni who become entrepreneurs by inviting alumni to join the Al Jawahir Alumni Association (IAA). The iaa managers always routinely help the implementation of vocational proficiency education in Boarding Schools Al Jawahir.

2. Vocational Proficiency Education Results

Vocational proficiency education results show that the performance of life skill education implementation is quite good determined through; (a) Implementation standards in accordance with the talents and interests of learners;

Resources consist of students, educators and educational personnel, as well as adequate facilities and infrastructure; (c) The organizational relationship between Boarding Schools and the Foundation is very good; (d) Characteristics of the implementing agent of competent educators (e) Social conditions in the form of good interaction between implementing agents, economic conditions, namely the Budget Plan of Boarding Schools;

a) Partnership

Partners are individuals and or institutions that have the potential to facilitate the sustainability of the program. The most preferred partners are those around the school so that they are responsible for improving the quality and relevance of the programs. Before the vocational program is implemented, it is necessary to make a cooperation agreement between Boarding Schools and partners that govern the rights and obligations of each party.

1) Partnerships implemented with the Government

Since the start of vocational proficiency education program in Boarding Schools Al Jawahir there has been a partnership with the Government, namely the Office of Cooperatives and MSMEs Bandung Regency, Bandung District Agriculture Office, and the Office of Cooperatives and MSMEs west Java Province, cooperation with the Office of Cooperatives and MSMEs West Java Province occurred in 2019 when Boarding Schools get assistance OPOP (One Boarding Schools One Product) from the Province.

2) Partnerships Implemented With Dudi

The partnership

conducted by Boarding 
Schools with DUDI

(Industrial Business

World) occurred in 2016, namely Boarding Schools

Al Jawahir in collaboration

with Ampera Gading

Soreang Restaurant and

Warung Makan Nasi Liwet

$\mathrm{Bu}$ Ika Soreang by

becoming a tempeh

supplier for both

restaurants. Then by

working together to be a

supplier of tempeh with

middlemen in Soreang

Market and Banjaran

Market, while for the

business of sewing shirts

there is no partnership

with DUDI, so only receive

simple stitches from the

foundation family.

Demands and

Expectations of Vocational

Skills Education in The

Improvement of

Entrepreneurial Spirit of

Students in Boarding

Schools Al Jawahir

3) Guidance of Vocational Skills Education in The Improvement of Entrepreneurial Spirit of Students in Boarding Schools Al Jawahir

The demands of vocational proficiency education in the improvement of entrepreneurial spirit of students in Boarding Schools Al Jawahir, starting from the lack of trust of the surrounding community in the world of work to the output issued by Islamic institutions Boarding Schools, especially in the world of industrial and office work. So that the output is marginalized with public educational institutions.

The task of Islamic educational institutions
Boarding Schools in particular, trying hard to catch up with the lag and setbacks of this nation by devoting all the ability to master science and technology dynamically and progressively in order to survive the life and meet the demands of society by through education oriented to the development of life skills. In essence the main task of boarding school is to realize people who believe and trust in Allah SWT. More especially boarding school as a production of ulama' with the quality of Islam, faith, science and morals santri expected to be able to build himself and the surrounding community. In addition, boarding schools also aim to create independent Muslim people who have self-help and self-help.

Vocasional skills are often referred to as vocational skills that are associated with certain areas of work in society. Therefore, Boarding Schools Al Jawahir must open itself to read various discourses on various problems of life so that the result becomes an intelligent, productive, creative, relegius outcome, because the community will be disappointed while the world of education produces people who are lazy, traditional, insensitive, and consumptive.

Boarding Schools openness is characterized by openness to the development of science 
and technology, as well as having the ability to anticipate the future. It is realized that the tendency to develop non-religious knowledge in Boarding Schools is a real need that must be faced by Boarding Schools graduates in the future. Precisely the challenge to compete to master non-religious knowledge is one of the tasks that must be carried out by Boarding Schools.

b) Hope of Vocational Skills Education in The Improvement of Entrepreneurial Spirit of Santri in Boarding Schools Al Jawahir

Boarding Schools Al Jawahir Soreang as one of the Islamic educational institutions seeks to open a global discourse that occurs in the community around the boarding school and the general public and various problems that arise among students after leaving Boarding Schools, such as the lack of creative santri after graduation in the sense that students do not know what to do, so it can be said that students are less capable in solving their life problems.

In the face of community guidance, Boarding Schools Al Jawahir integrates its educational patterns through various levels and corners in formal schools and outside formal schools, as well as various exercises and habituation patterns of independent living inherent to the daily lives of students that lead to the supply of life skills. Especially in vocational skills such as entrepreneurial learning, agrobusiness that includes the manufacture of tempeh, development of sewing skills santri and so on. Through this skill activity the entrepreneurial interest of the students is raised, to then be directed towards the development of economic business management when the santri returns to the community. With the aim of output not only master the field of religion or the hereafter but how the output can also survive the life with a variety of skills that it has.

Therefore, Boarding Schools Al Jawahir strives to develop life skills, especially vocational skills in the hope of helping students (students) to have self-esteem and confidence to make a living in the context of opportunities in their environment.

c) Problems faced in the implementation of vocational proficiency education in Boarding Schools Al Jawahir Boarding Schools Al
Jawahir in the
implementation of vocational
proficiency education is not
always smooth, but
sometimes there are
problems faced both
internally and externally.

\section{Internal Problems} Internal problems that occur in the implementation of vocational proficiency education in Boarding Schools Al Jawahir is the availability of equipment skills program seen in terms of the number of equipment and instructors with students as participants turned out to be disproportionate or inadequate. Other problems in the implementation of vocational proficiency education in Boarding 
Schools Al Jawahir, including: the training time available is very short, tutors are not sufficient, especially in the practice of tempeh making, and the practice space is inadequate.

Problems

vocational proficiency in

Boarding Schools Al

Jawahir that the training time is very short only once a week. It's best to do it every three weeks. In addition, there are still students who are lazy to participate in this activity.

d) External Issues

External problems that occur in the implementation of vocational proficiency education in Boarding Schools Al Jawahir is the absence of vocational skills training modules created by the Government for example by the Ministry of Religious Affairs Bandung Regency.

External problems in vocational skills in Boarding Schools Al Jawahir, lack of support from Parents Santri / Wali Santri. At the time of implementation sometimes there are still Santri parents who do not allow their children to participate in this activity. So, just wanting his son to focus on studying religion. In addition, the issue of partnership with the government, such as the issue of assistance of the old OPOP program liquid so as to make vocational proficiency activities are also hampered.

e) Anticipatory efforts and measures taken by Boarding Schools in solving the problem of vocational skills in Boarding Schools Al Jawahir

f) Efforts made by Boarding Schools in solving vocational skills problems in Boarding Schools Al Jawahir

The efforts made by Boarding Schools Al Jawahir in solving the problem of vocational skills in Boarding Schools Al Jawahir is to focus on the process of developing vocational skills.

In addressing internal problems, especially overcoming student laziness, the Boarding Schools seeks to focus on developing vocational skills with three stages, namely the teaching, habituation and assignment stages. The teaching referred to here is the provision of material either religious material or material about general knowledge. The habituation referred to here is to familiarize students in matters of entrepreneurial spirit improvement such as learning time discipline such as simple things to pray on time, discipline and so on. The assignment referred to here is to provide opportunities for students to practice the skills of sewing and making tempeh until the assignment of the sale of their products.

g) Anticipatory steps taken by Boarding Schools in solving vocational skills problems in Boarding Schools Al Jawahir Anticipatory measures taken Boarding Schools Al Jawahir in addressing management problems, namely: implementing professional management with a wide allocation of time, effective, and efficient and integral to the system and orientation of Boarding Schools development as a whole.

Related to the problem of standard facilities and limited equipment and 
inadequate practice space. Therefore, the efforts that Boarding Schools do is to refer to quality and continuous maintenance, pay attention to safety and security. Meanwhile, the problem of funds, efforts and anticipatory measures that Boarding Schools do is to implement breakthrough funding with financing schemes and sharia principles management. Fund management is also conducted professionally, accountably and transparently.

2. Findings from Boarding Schools Al Fadlilah Limbangan Garut Regency

Description of the findings in the research conducted at Boarding Schools Al Jawahir related to vocational skills education in the improvement of entrepreneurial spirit of students including vocational skills education developed, entrepreneurial values developed, implementation of vocational skills education, evaluation of vocational skills education, partnerships, demands and expectations, problems, anticipatory efforts and measures, and development models.

a. Vocational

Proficiency

Education

\section{1) Types of Vocational Proficiency Education}

From the results of interviews, observations, and documentation can be explained that vocational proficiency education developed in Boarding Schools Al Fadlilah is the provision of basic insights and elementary skills in agriculture and graphic design.

In agriculture for example, there are coffee plantations that are processed into coffee perguji. Coffee perguji is sold to businessmen coffeshop so that al Fadililah coffee has subscribed with one of the Coffee Cafe in Limbangan so that the Cafe also gave the name café Cafe Perguji Coffee. While in the field of graphic design, students are expected to be able to know the basic material, able to practice the material understood, able to live independently, and able to develop further skills.

2) Why Boarding Schools

Choose this Type of

Vocational Proficiency

Education

From the results of interviews, observations, and documentation can be explained that the reason Boarding Schools Al Fadlilah chose coffee making programs and graphic design skills, because Boarding Schools since its inception already has a coffee plantation that wants to be mass produced by students and Alumni.

The first reason that makes this coffee business quite profitable is the steady trend of consumer development. One of the causes of the steady development of consumers is one of the increasing number of consumers choosing to drink coffee in coffeeshops instead of at home. Even today's coffee culture also gives birth to many coffee consumers who have a unique character. Even the new generation today rarely consume coffee sachets, because they can get to know coffee directly from the baristas in coffeeshop one of them in Limbangan this Coffeshop Perguji Coffee.

The role of social media to coffee perguji is also so great with the promotion and marketing system that is now increasingly more options, making the potential of coffee perguji known even greater.

The reason for choosing graphic design skills, because 
today's digital era of graphic design position is very important and definitely needed. Even graphic design job positions do not infrequently promise a sufficient salary.

a) Can Open New Business Opportunities

Students who do not like jobs tied to an agency or company, learning graphic design can be an option to open new business opportunities. Nowadays many graphic design freelances are successfully carrying out their work.

Such as open logo making services, pamphlets, invitations and others. Or if students find it difficult to promote your own design business, students can visit a graphic design freelance site, then register as a freelance worker on the site. if anyone is interested in your design, aka the order notification tone. Exciting, not only will meet with domestic customers, students are very likely to get orders from foreign citizens who access the site and need its services.

b) Increase Creativity

By studying graphic design, santri directly also improves its creative spirit, because the mindset will definitely be directed to new things, creative and could have not been thought of by others. Learning graphic design makes students will be more innovative in doing other work as well.

c) Shorten Work

Indirectly, design can make people's work shorter and simpler. For example, in making proposals, if students have expertise in design, students no longer need to draw up proposals with a lot of writing and complex. Simply include important points in the design as attractive as possible, so the proposal will be easier and understandable to the target. d) Become a Skill to be proud of in the Digital Age

Expertise in graphic design is an important skill in today's digital age. Especially in completing the CV and work experience of students. Having graphic design skills is also worth more for many people, because not many people are really experts in this field. Therefore, it will be more seen hrd when applying for a job if students have this advantage.

e) It's easier to say something

Nowadays most people have a low interest in reading, tend to be lazy to read captions or long posts. Through a design, it can make it easier for people to draw conclusions about a message. For example, when students sell bag products on Instagram, people will definitely read the picture first rather than the caption. Especially if the caption is Long, kayanya will skip immediately. Through a design in the form of pamphlets or photos, prospective buyers are easier to capture the message delivered and easier to be tempted by the promotion.

\section{3) Vocational Proficiency \\ Education Indicators \\ Success}

From the results of interviews, observations, and documentation can be explained that the indicators of the success of vocational skills education in Boarding Schools Al Fadlilah is directed at the achievement of three competencies that include entrepreneurial planting, understanding concepts and skills, with a greater weight on the achievement of competencies of the soul of skills compared to the understanding of concepts including:

(a) The integration of Entrepreneurship Education in 
Materials / Textbooks

Materials/ textbooks is the most influential learning component to what actually happens in the learning process. Generalization of entrepreneurial values can be done into teaching materials both in material exposure, tasks and evaluations.

(b)Integration of Entrepreneurship Education Through Cultural Boarding Schools Culture / Boarding Schools culture is the atmosphere of Boarding Schools life where students interact with others, ustadz with ustadz, counselors with others, administrative employees with others, and between members of school community groups.

(c) The development of values in entrepreneurial education in Boarding Schools culture includes activities carried out by Boarding Schools leaders, Ustadz/Ustadzah, Tutors, when communicating with students and using Boarding Schools facilities, such as honesty, responsibility, discipline, commitment and entrepreneurial culture in the Boarding Schools environment (all Boarding Schools citizens conduct entrepreneurial activities in the school environment).

Vocational education orientation in Boarding Schools Al Fadlilah is to facilitate emotional, intellectual, physical, perception, social, aesthetic, artistic, and creativity experiences of students by conducting appreciation and creation activities on various products This activity starts from identifying the potential around learners to be transformed into a useful product for human life. Learning is systematically designed through the stages of imitating, modifying, and transforming the functionality of existing products towards new, more useful products. Vocational education in Boarding Schools Al Fadlilah Limbangan has the following objectives and scopes:

(a) Purpose

1) Able to develop knowledge and skills to make a variety of craft products and technological products that are useful for human life.

2) Have a sense of aesthetics, appreciation of handicraft products, technology products, and artifacts from various regions of the archipelago and the world.

3) Able to identify potential local areas that can be developed through crafting and utilization of simple technology.

4) Have a professional and entrepreneurial attitude.

(b)Scope

1) Craft skills.

2) Utilization of simple technologies that include engineering technology, cultivation technology, and processing technology.

3) Entrepreneurship

4) Vocational

Education

Skills

Document

From the results of interviews, observations, and documentation can be explained that Boarding Schools Al Jawahir Soreang has several planning documents for vocational skills education planning program contained in the Boarding Schools program document consisting of:
(a) Long-term Boarding Schools program or Long-Term Boarding Schools Work Plan (RKPJP). RKPJP is between 8-10 years old.
(b) Vocational proficiency education Boarding Schools 
program in Boarding

Schools Al Fadlilah

Limbangan only contained

in the RKPJP document is

not explained again in the

middle work plan.

5) Sources of Funding in Vocational Proficiency Education

From the results of interviews, observations, and documentation can be explained that the source of funds in vocational proficiency education in Boarding Schools Al Fadlilah consists of donors, government assistance, and business units Boarding School.

Boarding School Al Fadlilah has donors, namely a Coffeshop Entrepreneur in garut area who every year routinely provides funds for vocational skills education, Boarding Schools Al Fadlilah has also worked with the Office of Cooperatives and MSMEs of West Java Province in 2019 in the OPOP (One Boarding Schools One Product) program.

\section{b. Entrepreneurial Values}

1) Vocational Proficiency Education Values developed

From the results of interviews, observations, and documentation can be explained that the entrepreneurial values developed in Boarding Schools Al Fadlilah Limbangan namely Creative innovative values and flexibility are elements of one'sorisinilan. Innovative entrepreneurs are creative people who are confident in new, better ways, with characteristics:

(a) Never satisfied with the ways that are done today, although the way is quite good.

(b)Always pouring imagination in his work.

(c) Always want to stand out or make the most of differences.

2) Boarding Schools Method in Developing Entrepreneurial Spirit of Students
From the results of interviews, observations, and documentation can be explained that the boarding school method used to develop the entrepreneurial spirit of santri is to balance the functions of the human brain divided into two parts, namely the right brain and the left brain. humans use the right brain to learn to develop creative skills with the following characteristics:

(a) Always ask, "Is there a better way?"

(b) Always challenging habits, traditions and routines.

(c) Reflect or reflect and think deeply.

(d)Dare to play mentally, try to see the problem from a different perspective.

(e) Be aware of the possibility of many answers rather than one correct answer.

(f) See failure and mistakes only as a way to achieve success.

(g) Correlate vague ideas to problems to produce innovative solutions.

(h) Having a "helicopter plan", which is the ability to rise above routine habits and see the problems of the wider perspective then focus it on the need to change.

While the left brain is used to develop thinking skills. There are seven steps of the creative process:

(a) Preparation

Preparation concerning readiness to think creatively, conducted in the form of formal, experience, internship and other learning experiences.

(b) Investigation

In the investigation is required individuals who can develop a deep understanding of the problem or decision. To create new concepts and ideas about a field, one must first study the problem and understand its basic components.

(c) Transformation 
The stage of transformation concerns the similarities and differences of views among the collected information. Transformation is to identify existing similarities and differences about the information collected. In this stage it takes two types of thinking, namely convergent thinking and divergence. Convergent thinking is the ability to see similarities and relationships between diverse data and events. While divergent thinking is the ability to see the difference between data and diverse events.

(d) Hatching

Hatchery is the preparation of the subconscious mind to ponder the information gathered. The subconscious mind takes time to reflect information.

(e) Lighting

Lighting will appear at the hatchery stage, which is when there is a spontaneous breakdown that causes a bright spot. At this stage, all the previous stages came together and produced creative and innovative ideas.

(f) Testing

Testing concerns the validation of the accuracy of the benefits of emerging ideas that can be done during the experiment, simulation process, marketing tests, construction of experimental projects, construction of prototypes and other activities designed to prove new ideas to be implemented.

\section{3) Internalization of Entrepreneurial Values of Students}

From the results of interviews, observations, and documentation can be explained that the internalization of entrepreneurial values implemented in Boarding Schools Al Fadlilah Limbangan is started from the process of forming entrepreneurial spirit using core values that are integrated into the community empowerment process is a learning strategy that is implemented more effectively when using various approaches that suit the needs of the community and in accordance or appropriately with the problem of keh in the community. This means that the approach used can take the form of problem solving or actual case studies occurring in the community.

The process of internalizing the values of entrepreneurship students in Boarding Schools Al Fadlilah Limbangan seen from the perspective of social influence of entrepreneurship, the findings of research show there is a dependency culture (culture of interdependence), pilot culture, tradition and religious culture, culture of success and failure, social network. On the sociosolytic side of interdependence with business people, we have the principle of helping each other by setting an example with the support of creative ability, holding tradition, and joint commitment to the sociological side, worship with the availability of local resources and government support.

The students studied have a strong pilot culture in an effort to support the existence of social security networks in the community, with their ability as inspiration in their respective capacities. The culture of Javanese tradition and religious religion (Islam) color the sociological behavior that tidan separated from the individual behavior of the three informant entrepreneurs. This traditional social behavior color their vision of success and failure usa-ha, make them steadfast and persistent, have the ability of self-control, confidence, this can be analyzed that in business does not always experience success even tends to several times fail.

Addressing sociologically, for students failure and success 
has been supported by social networks around the business, awareness of interdependent precisely encourages fortitude and persistence and strives to be independent, learn from success and failure, make energy and high spirit to strive.

Social security network in relation to consumers, suppliers, business partners, and associations becomes the core that is inseparable from entrepreneurs in Garut. This social context has formed a vision, a culture of interdependent, commitment to others, in conditions of market uncertainty, creativity of policy controllers in industrial centers and independent actors entrepreneurs in Garut. Social safety networks that mean the synergy of business people appear to be a social fact that can be ignored in forming an entrepreneurial learning model.

Furthermore, when viewed from the perspective of entrepreneurial personality santri. From the perspective of student personality, the study findings show that the personality values that students have include: tolerance to risk, tolerance to uncertainty, vision, inspiring capacity, creativity, firm internal supervision, stoic and persistent, self-control, confidence, and high energy / spirit.

Tolerance to risk always means that negative risks are faced vigorously by the students. From the narrative of the students there is a side where tolerance to risk has strengthened their personality in the context of encouragement to be more independent, steadfast and persistent, proactive in dealing with problems, precisely generate creativity and make it as an inspiring capacity and learning opportunities in the face of existing risks.
Tolerance to inaccuracies is done basically with different strategies by actors, it could be by strict internal control of students, building networks with established entrepreneurs, and providing tolerance to the risks faced.

Self-control ability is
internalization of learning
outcomes because no business does not fall up and this is ultimately related to the growth of confidence in business. The struggle to give up with the support of different educational backgrounds does not discourage attitudes to struggle and encourages making choices to be independent are the values that exist in entrepreneurs.

Judging from the perspective of the macro conditions of students who will open a business, the research findings show that there are several conditions that form the attitude and behavior of business, namely: changes in market conditions, availability of local environmental facilities, control over the availability of local environmental resources and facilities, financial access, the ability to build partners and aliansi, as well as the role and support of the government. This environmental condition has enough meaning in shaping the attitudes and behaviors of students who will open a business.

\section{CONCLUSION}

Vocational skills education in an effort to improve the entrepreneurial spirit in Boarding Schools is still not maximal. It is proven that only a few Boarding Schools graduates have an entrepreneurial spirit. Vocational proficiency education in boarding schools is more likely to provide theory than practice so that the learning stategi provided is less comprehensive, innovative, and creative. 


\section{REFERENCES}

Abdullah, Said. (2007). Pesantren Jati Diri dan Pencerahan Masyarakat. Sumenep: Said Abdullah Institute Publishing.Googhle Scholer

Azra, Azyumardi. (1999). Pendidikan Islam: tradisi dan modernisasi menuju milenium baru. Logos Wacana Ilmu. Googhle Scholer

Cahyono, Bayu Dwi. (2017). Manajemen Pengembangan Pendidikan Kewirausahaan Guna Peningkatan Kecakapan Hidup Bagi Santri Di Pondok
Modern Darussalam Gontor Kampus 2 Ponorogo. Program Studi Pendidikan Islam, Program Pascasarjana, UIN Sunan Kalijaga Yogyakarta. Googhle Scholer

Khamidah, Nur. (2018). Pendidikan kewirausahaan untuk meningkatkan life skill santri di Yayasan Pondok Pesantren Modern Yatim dan Dhuafa Madania Yogyakarta. Universitas Islam Indonesia. Googhle Scholer

\section{Copyright holder:}

Retno Anisa Larasati, Iim Wasliman, Hanafiah, Waska Warta (2021)

First publication right:

Journal of Social Science

This article is licensed under:

(c) (i) (2) 